\title{
ANALYSIS OF LAND COVER CHANGES IN MANGROVE VEGETATION USING LANDSAT IMAGE DATA IN COASTAL, SUNGAI APIT DISTRICT, SIAK REGENCY, RIAU PROVINCE
}

\author{
Armanda $^{1}{ }^{*}$, Mubarak $^{1}$, Elizal $^{1}$ \\ ${ }^{1}$ Department of Marine Science, Faculty of Fisheries and Marine Universitas Riau, Pekanbaru \\ *mandajr213@gmail.com
}

\begin{abstract}
This research was conducted in March-April 2021 in the Coastal District of Sungai Apit, Siak Regency, Riau Province. The purpose of this study was to analyze changes in the land cover area of mangrove vegetation and mangrove vegetation index in Sungai Apit District, Siak Regency, Riau Province. The method used in this study is a survey method with the interpretation of Landsat image data recorded in 2000, 2005, 2010, 2015, 2020. The results of the study obtained that mangrove forests with the highest area were in 2000 with an area of mangrove vegetation reaching 7990,586 ha and there was a decline with the lowest number in 2015 with a vegetation area of 486,43 ha and in 2020 the mangrove vegetation area of 497,511 ha. Overall as much as $79 \%$ of the mangrove forest area has been damaged and changed its function within a period of 20 years. The NDVI value in Sungai Apit District is moderate with a value of $0,3-0,5$, the category of meeting with a value of $0,5-0,6$, and the very dense category of $0,6-0,8$.
\end{abstract}

Keywords: Sungai Apit District, Mangrove, Citra Landsat.

\section{PENDAHULUAN}

Ekosistem mangrove merupakan tipe hutan daerah tropis yang khas tumbuh di sepanjang pantai atau muara sungai yang masih dipengaruhi oleh pasang surut air laut. Ekosistem mangrove banyak dijumpai di wilayah pesisir yang terlindungi dari gempuran ombak. Pengertian ekosistem mangrove secara umum merupakan komunitas vegetasi pantai tropis yang didominasi oleh beberapa jenis pohon mangrove yang tumbuh dan berkembang pada daerah pasang surut pantai berlumpur [1].

Sumber daya hutan mangrove memiliki fungsi dan peranan yang pentig dalam kehidupan manusia, baik sebagai sumber hasil hutan maupun sebagai pelindung pantai/pesisir dari serangan ombak, arus dan angin. Disamping itu mangrove memiliki peranan unik yang tidak dapat digantikan oleh hutan maupun ekosisitem lainnya yaitu sebagai mata rantai perputaran hara yang sangat penting bagi organisme aquatik [2].

Potensi ekosistem mangrove di daerah Kecamatan Sungai Apit, Kabupaten Siak yang cukup besar memberikan peluang yang besar terhadap terciptanya berbagai bentuk pemanfaatan mangrove secara ekonomi. Bentuk bentuk pemanfaatan secara ekonomi tersebut misalnya usaha pertambakan, pariwisata, penangkapan ikan dan industri. Bentukbentuk pemanfaatan diatas masih menempatkan pemanfaatan sumber daya alam (terutama ekosistem mangrove) di wilayah pesisir sebagai pilar utama pengembangan wilayah di kawasan ini. Sementara, pilar-pilar yang lain yakni sumber daya manusia dan teknologi umumnya masih relativ tertinggal. Fakta ini 
merupakan kondisi umum di kawasan pesisir Provinsi Riau.

Pemantauan perubahan luasan hutan mangrove merupakan suatu usaha pengendalian terhadap degradasi ekosistem mangrove. Salah satu upaya untuk memperoleh informasi tentang potensi sumberdaya wilayah pesisir dan lautan dalam rangka untuk mengoptimalkan pengelolaan wilayah pesisir dan lautan adalah penggunaan teknologi Remote Sensing atau penginderaan jauh. Teknologi informasi geospasial merupakan salah satu teknologi yang dapat digunakan untuk inventarisasi dan monitoring perubahan kondisi sumberdaya alam secara lebih efisien, termasuk diantaranya sebaran mangrove. Selama ini perubahan luas tutupan lahan vegetasi mangrove pesisir Kecamatan Sungai Apit, Kabupaten Siak,
Provinsi Riau belum pernah diteliti dengan pendekatan teknologi informasi tersebut. Atas dasar itulah penelitian sangat perlu dilakukan.

\section{METODE PENELITIAN Waktu dan Tempat}

Penelitian ini dilaksanakan pada bulan Maret-April 2021. Wilayah kajian mencakup ekosistem mangrove di Pesisir Kecamatan Sungai Apit, Kabupaten Siak, Provinsi Riau, yakni di Pesisir Desa Mengkapan, Desa Kayu Ara, dan Desa Lalang. Selanjutnya interpretasi peta dan analisis data dilakukan di Laboratorium Oseanografi Fisika Jurusan Ilmu Kelautan, Fakultas Perikanan dan Kelautan Universitas Riau. Lokasi penelitian dapat dilihat pada Gambar 1.

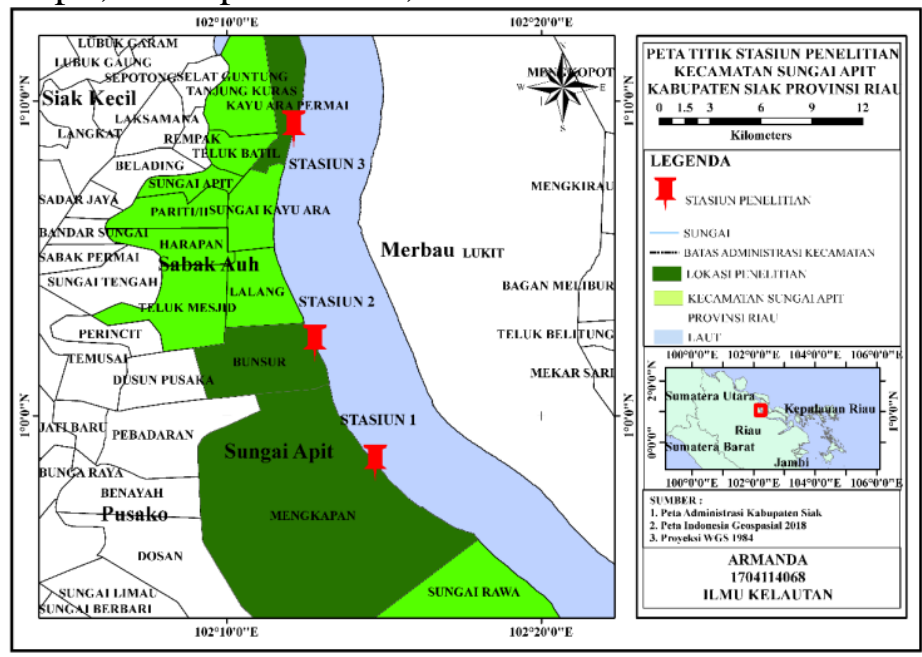

Gambar 1. Peta Lokasi Penelitian

\section{Metode Penelitian}

Metode yang digunakan dalam penelitian ini adalah metode survey dengan interpretasi data citra Landsat yang direkam pada tahun 2000, 2005, 2010, 2015, 2020 yang digunakan berbagai perangkat lunak (software) pengolahan citra digital, dimana tutupan lahan vegetasi merupakan luasan lahan yang ditumbuhi oleh keseluruhan komunitas tumbuhan di suatu tempat tertentu, mencakup perpaduan komunal dari jenis jenis flora penyusunan tutupan lahan (ground cover) yang terbentuk. Luasnya daerah yang diteliti maka digunakan metode survei di lapangan atau ground checking dengan cara menentukan titik koordinat lokasi yang akan diteliti menggunakan citra. Selain itu juga menggunakan data statistik dan data kerapatan mangrove di beberapa wilayah sampling stasiun penelitian ditentukan secara purposive sampling yang artinya stasiun penelitian dipilih secara sengaja berdasarkan pertimbangan kondisi pesisir dari hasil pengolahan data citra kemudian analisis data dilakukan secara deskriptif. 


\section{Prosedur Penelitian}

\section{Analisa Citra}

Analisa citra digunakan dalam melihat kondisi dan perubahan luasan mangrove di Kecamatan Sungai Apit, Kabupaten Siak tahun 2000 sampai tahun 2020 adalah dengan menggunakan metode tumpang susun/overlay. Jenis overlay yang digunakan adalah jenis overlay union. Menurut [3], overlay adalah analisis spasial yang mengkombilasikan 2 tematik masukannya. Overlay union adalah analisis yang mengkombinasikan unsur-unsur spasial yang menghasilkan layer baru yang berdomain spasial terluas.Kemudian analisi data hasil pengelolaan citra dalam penelitian ini yaitu data yang diperoleh kemudian disajikan dalam bentuk peta table kemudian dibahas dan dianalisa secara deskriptif dari hasil olahan data menggunakan Software ENVI4.5 dan ArcGIS v10.4

\section{Analisis Normalized Different Vegetation Indeks (NDVI)}

Analisis Normalized Different Vegetation Indeks (NDVI) adalah Transformasi indeks vegetasi secara umum dapat memberikan informasi mengenai kerapatan tutupan vegetasi. Algoritma transformasi indeks vegetasi pada umumnya menggunakan saluran merah dan inframerah dekat, karena kedua saluran tersebut memiliki kepekaan yang mencolok terhadap objek vegetasi. Pada saluran merah nilai pantulan vegetasi sangat rendah berbanding terbalik dengan saluran inframerah dekat yang memiliki pantulan sangat tinggi pada objek vegetasi. NIR/RED klasifikasi nilai NDVI adalah sebagai berikut: kerapatan sangat jarang (nilai NDVI 0-0,2), kerapatan jarang (nilai NDVI 0,2-0,3), kerapatan sedang (nilai NDVI 0,3-0,5), kerapatan rapat (nilai NDVI 0,5-0.6), kerapatan sangat rapat (nilai NDVI 0,6-0,8).

$$
\text { NDVI }=\frac{(\text { NIR-VIS })}{(\text { NIR+VIS })}
$$

Keterangan:

$$
\begin{aligned}
\text { NDVI }= & \text { Normalized } \\
& \text { Vegetation Indeks } \\
\text { NIR }= & \text { Near Infra Red } \\
\text { VIS }= & \text { Visible Red }
\end{aligned}
$$

Dalam hal ini kriteria-kriteria nilai NDVI ditampilkan pada Tabel 1

Tabel 1. Klasifikasi NDVI

$\begin{array}{ll}\text { Kriteria } & \text { NDVI } \\ 0,1-0,2 & \text { Sangat Jarang } \\ 0,2-0,3 & \text { Jarang } \\ 0,3-0,5 & \text { Sedang } \\ 0,5-0,6 & \text { Rapat } \\ 0,6-0,8 & \text { Sangat Rapat }\end{array}$

\section{HASIL DAN PEMBAHASAN Luasan Mangrove}

Berdasarkan hasil penelitian

\begin{tabular}{|c|c|c|c|c|c|c|}
\hline \multirow[t]{2}{*}{ Stasiun } & \multicolumn{5}{|c|}{ Luasan Pertahun } & \multirow[t]{2}{*}{ Keterangan } \\
\hline & 2000 & 2005 & 2010 & 2015 & 2020 & \\
\hline Mengkapan & 6053,81 & 7101,75 & 4740,05 & 249,35 & 249,81 & Berkurang \\
\hline Bunsur & 1021,74 & 1514,58 & 601,3 & 68,39 & 68,08 & Berkurang \\
\hline Kayu Ara Permai & 915,04 & 814,46 & 485,49 & 168,69 & 179,62 & Berkurang \\
\hline Jumlah & 7990,59 & 9430,79 & 5826,84 & 486,43 & 497,51 & \\
\hline
\end{tabular}
penginderaan jauh pada 3 stasiun didapat luas mangrove tahun 2000-2020 cenderung mengalami penurunan luasan (Tabel 2).

Tabel 2. Luas Mangrove Tahun 2000-2020 Berdasarkan Analisis Data Citra

Berdasarkan analisis citra dengan metode supervised classification terjadi perubahan fluktuasi antar pengamatan di Kecamatan Sungai Apit pada tahun 2000- 
2020 dengan interval sampai 5 tahun (Gambar 2).

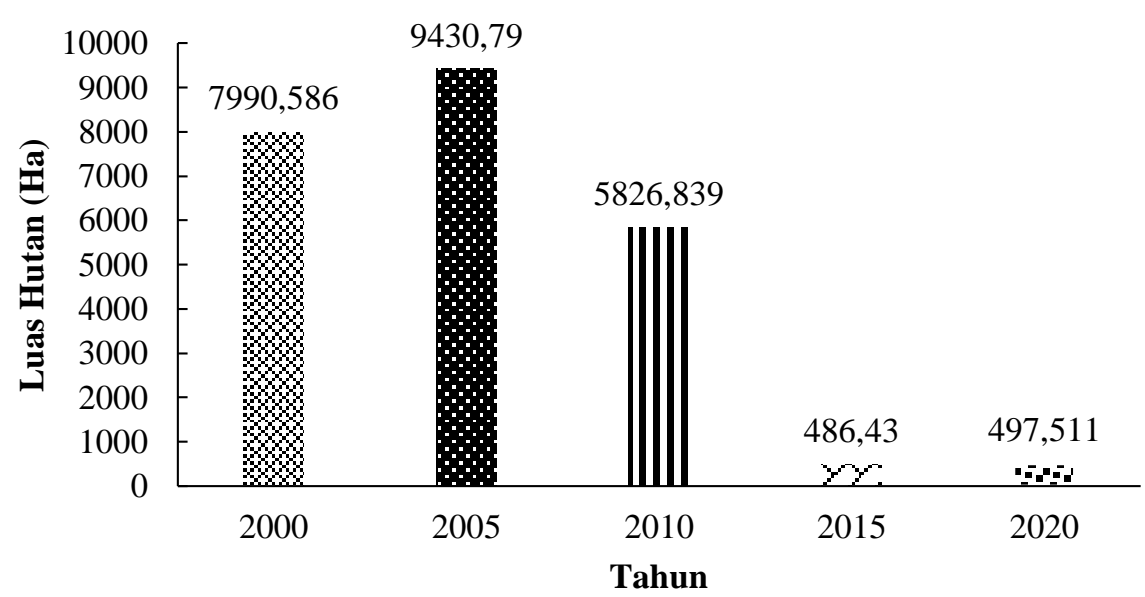

Gambar 2. Luas Vegetasi Hutan Mangrove Kecamatan Sungai Apit Berdasarkan Analisis Citra Landsat

Perubahan Luas Vegetasi Mangrove Desa Mengkapan (Stasiun I)

Stasiun pengamatan di Desa Mengkapan diperoleh nilai luas tutupan

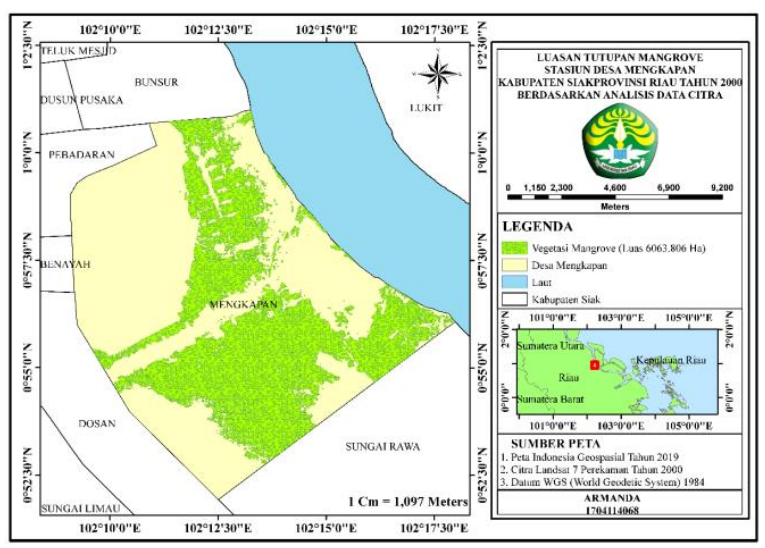

Gambar 3. Luas Vegetasi Mangrove Tahun 2000

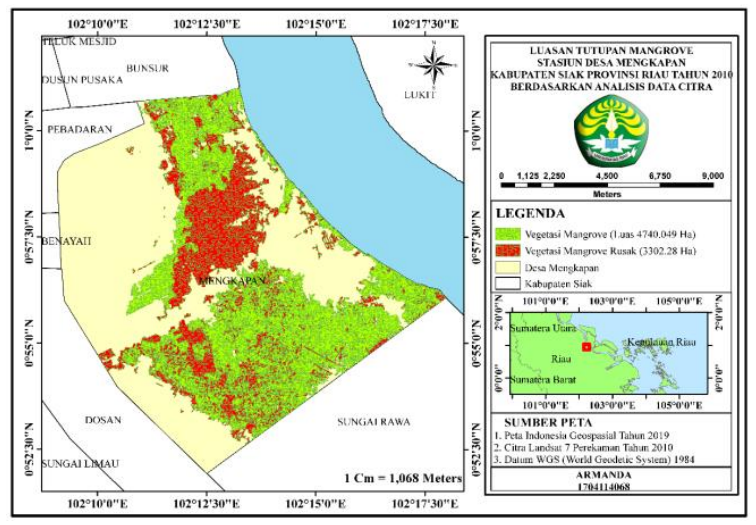

Gambar 5. Luas Vegetasi Mangrove Tahun 2010 mangrove pada tahun 2000, 2005, 2010, 2015, dan 2020 maka diperoleh secara rinci dapat dilihat pada Gambar 3,4,5,6, dan 7 .

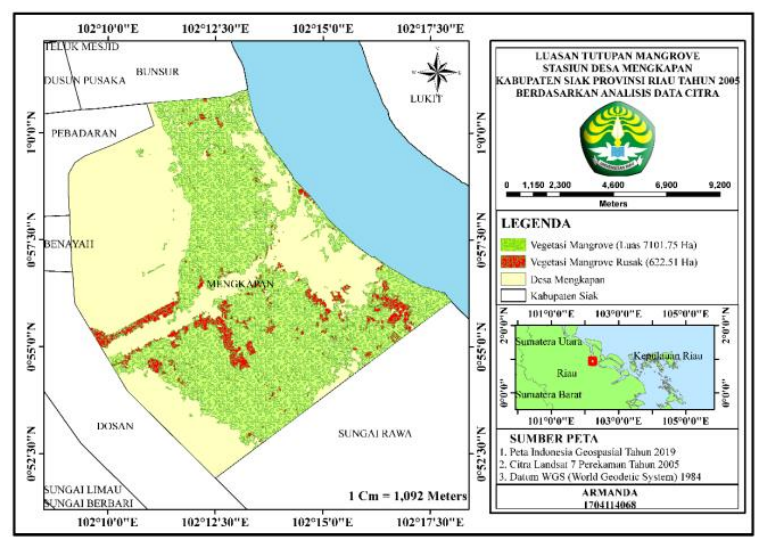

Gambar 4. Luas Vegetasi Mangrove Tahun 2005

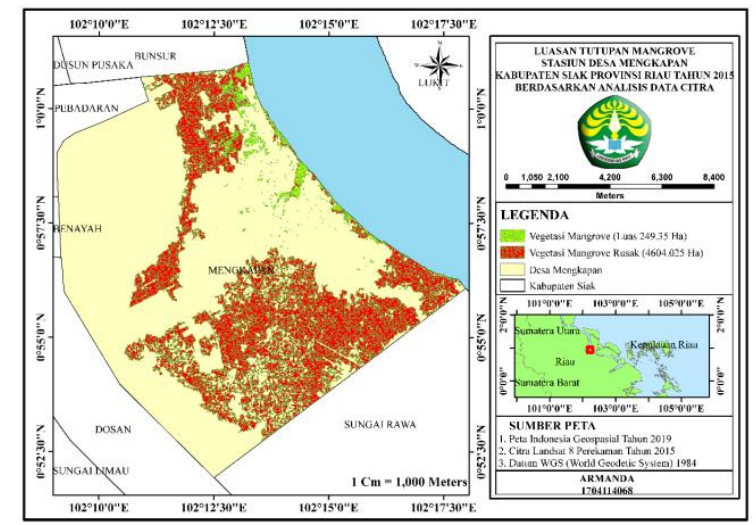

Gambar 6. Luas Vegetasi Mangrove Tahun 2015 


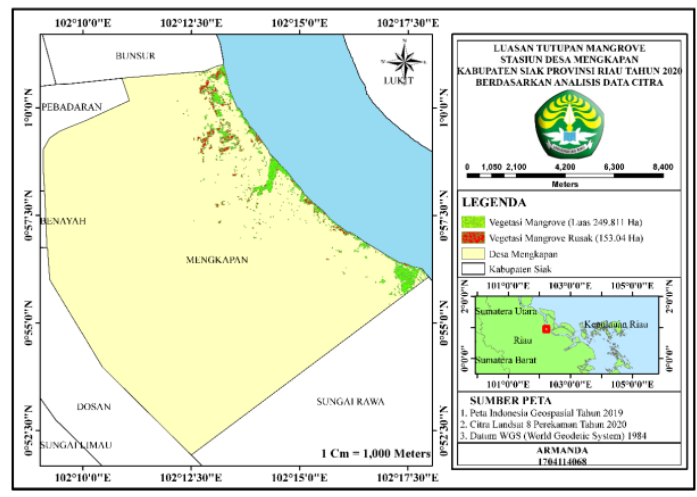

Gambar 7. Luas Vegetasi Mangrove Tahun 2020

Pada Stasiun I Desa Mengkapan diperoleh nilai tutupan lahan mangrove mulaidari tahun 2000 sampai tahun 2020 mengalami penurunan jumlah luas vegetasi. tahun 2000 luas mangrove mencapai 6053,81 ha dan mengalami peningkatan jumlah luas vegetasi pada tahun 2005 mencapai 7101,75 ha. pada tahun 2010 sampai tahun 2015 mengalami penurunan mulai dari 4740,05 ha menjadi 249,35 dan

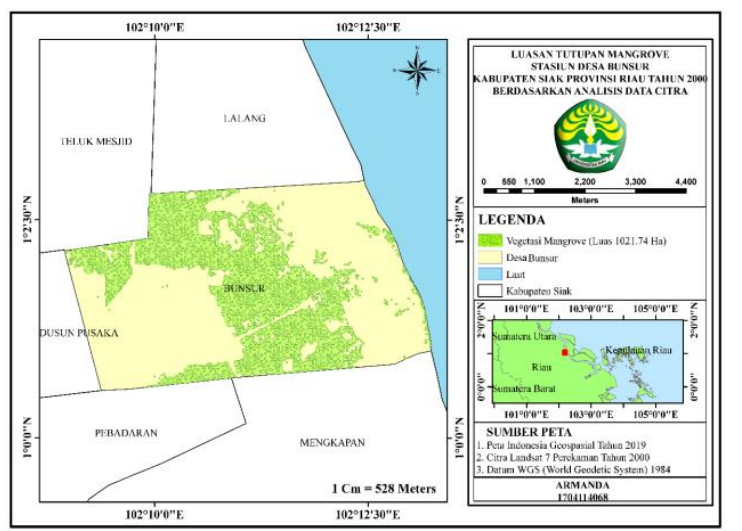

Gamber 8. Luas Vegetasi Mangrove Tahun 2000

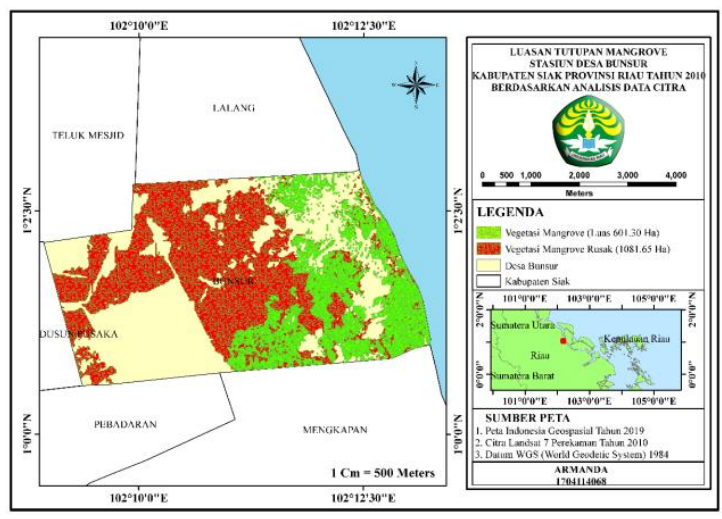

Gambar 10. Luas Vegetasi Mangrove Tahun 2010 pada tahun 2020 jumlah luas vegetasi mengrove 249,81 ha.

\section{Perubahan Luas Vegetasi Mangrove Desa Bunsur (Stasiun II)}

Pengamatan di Stasiun II Desa Bunsur diperoleh nilai tutupan lahan mangrove pada tahun 2000, 2005, 2010, 2015, dan 2020 maka diperoleh nilai secara rinci pada Gambar 8,9,10,11, dan 12 .

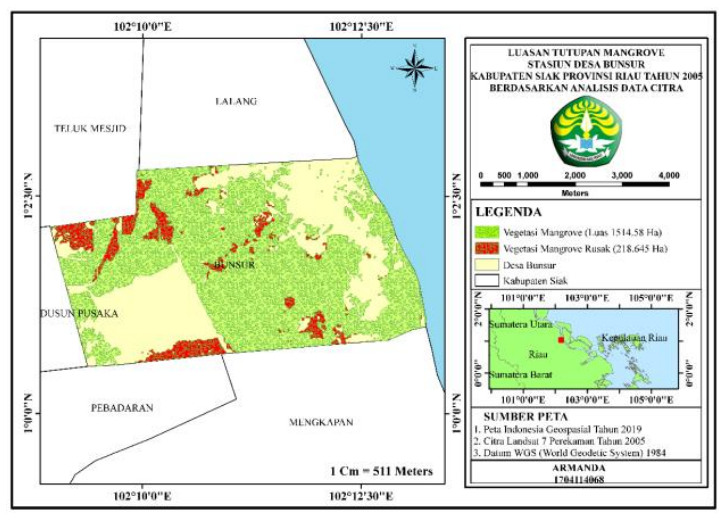

Gambar 9. Luas Vegetasi Mangrove Tahun

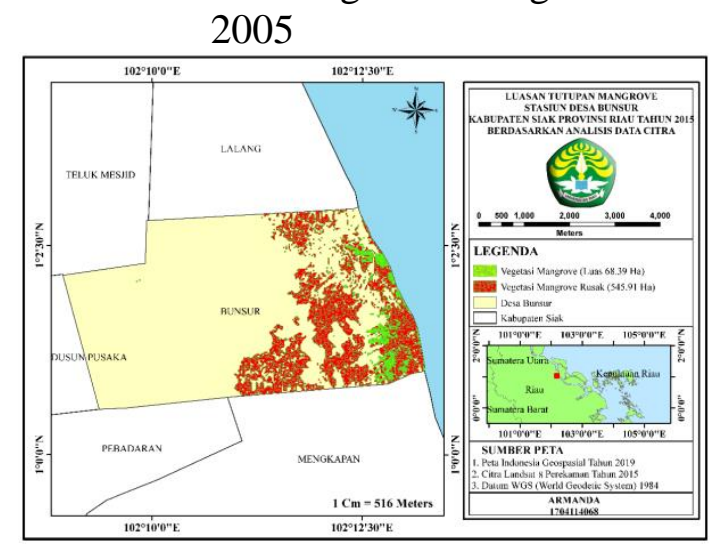

Gambar 11. Luas Vegetasi Mangrove Tahun 2015 


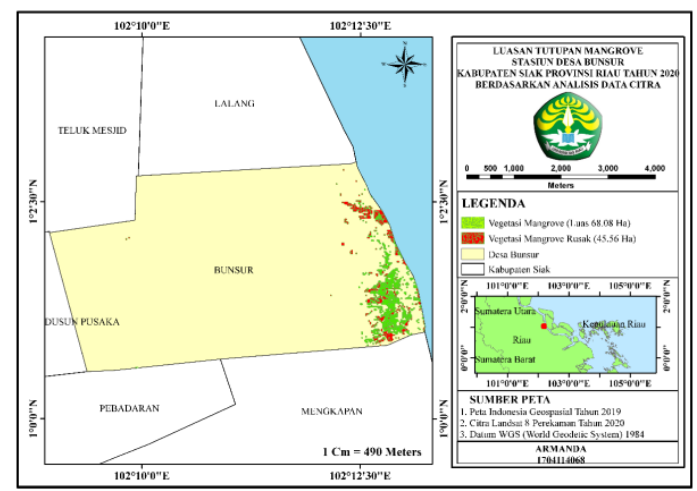

Gambar 12. Luas Vegetasi Mangrove Tahun 2020

Tutupan mangrove di stasiun Desa Bunsur menurut data citra diperoleh vegetasi mengrove mengalami penurunan. Tahun 2000 luas mangrove mencapai 1021,74 ha dan mengalami peningkatan jumlah luas vegetasi pada tahun 2005 mencapai 1514,58 ha. pada tahun 2010 sampai tahun 2015 mengalami penurunan mulai dari 601,3 ha menjadi 68,39 dan pada

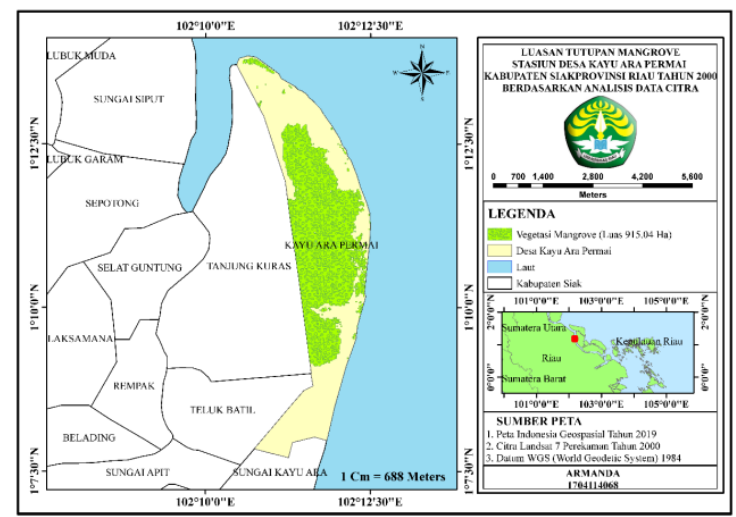

Gambar 13. Luas Vegetasi Mangrove Tahun

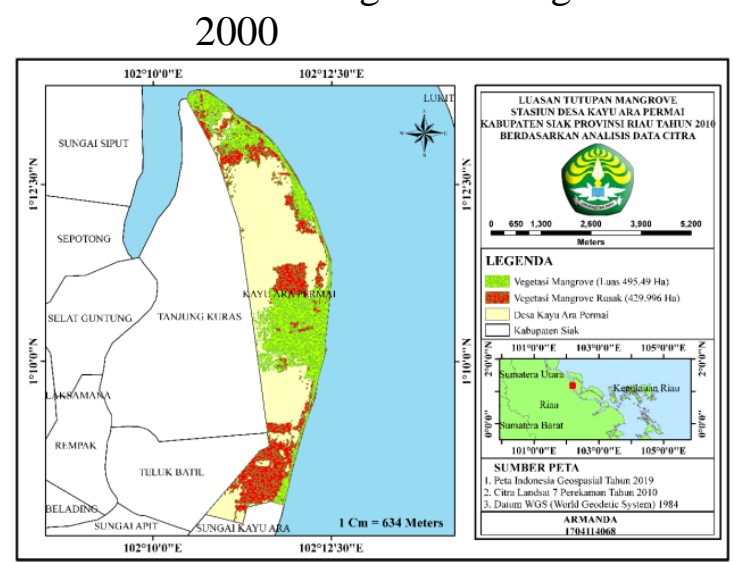

Gambar 15. Luas Vegetasi Mangrove Tahun 2010 tahun 2020 jumlah luas vegetasi mengrove 68,08 ha.

\section{Perubahan Luas Vegetasi Mangrove Desa Kayu Ara Permai (Stasiun III)}

Pengamatan di Stasiun III Desa Kayu Ara Permai diperoleh nilai luasan tutupan mangrove pada tahun 2000, 2005, 2010, 2015, dan 2020 secara rinci dapat dilihat pada Gambar 13,14,15,16, dan 17.

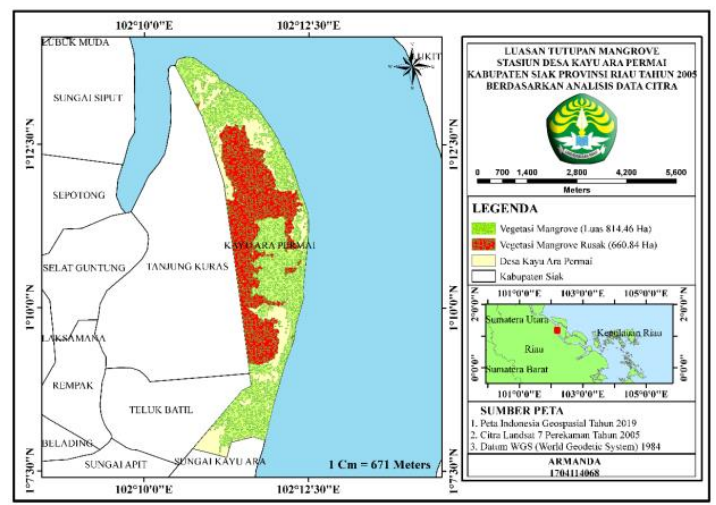

Gambar 14. Luas Vegetasi Mangrove

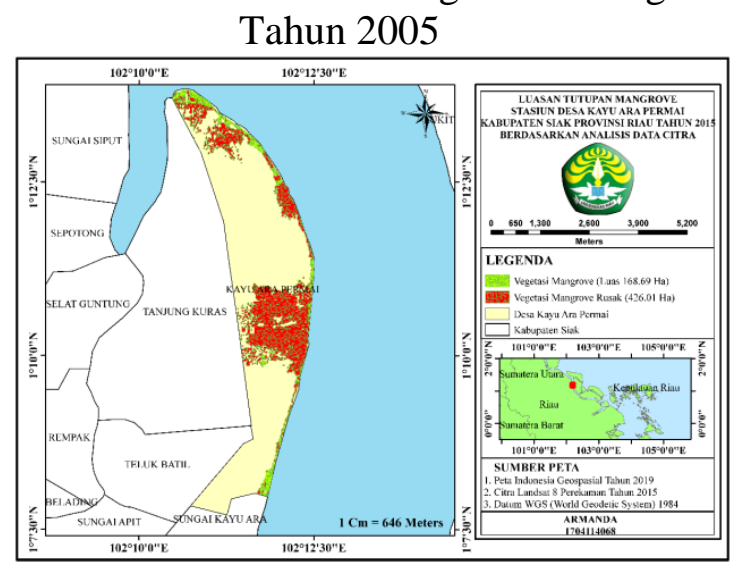

Gambar 16. Luas Vegetasi Mangrove Tahun 2015 


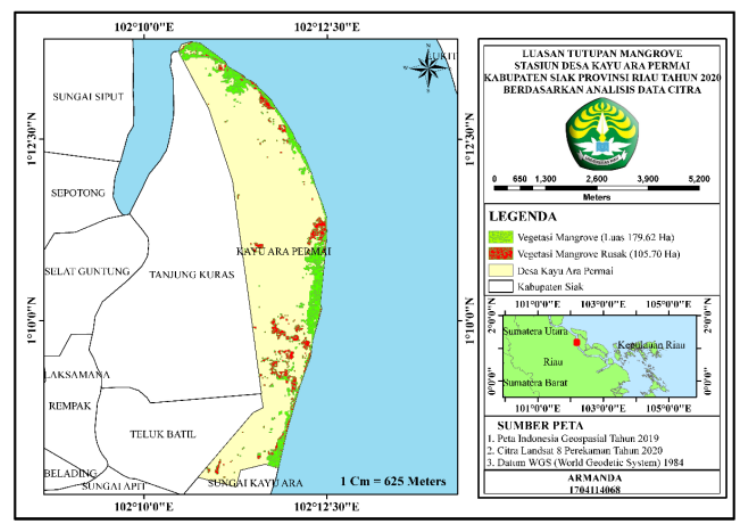

Gambar 17. Luas Vegetasi Mangrove Stasium III Tahun 2020

Luasan vegetasi mengrove terjadi penurunan antara tahun 2000 sampai tahun 2015 dimana pada tahun 2000 vegetasi mangrove mencapai 915,04 ha sampai tahun 2015 luas vehetasi mencapai 168,69 ha. Diperkirakan hal ini terjadi karena adanya perluasan daerah pemukiman. Pada tahun 2020 terjadi pertambahan jumlah vegetasi yang mencapai 179,62 ha.

Berdasarkan data luasan vegetasi mangrove Kecamatan Sungai Apit, Kabupaten Siak mengalami peningkatan dan penurunan mulai dari tahun 2000 sampai tahun 2020. Pada tahun 2000 sampai 2005 perubahan vegetasi hutan mangrove mengalami peningkatan mulai dari 7990,586 ha menjadi 9430,79 ha. Pada tahun 2005 sampai tahun 2015 cendrung mengalami penurunan jumlah vegetasi sampai 486,43 ha. Dan pada tahun 2020 mengalami peningkatan vegetasi mengrove sampai 497,51 ha.

Kerusakan alamiah yang sering terjadi pada ekosistem mangrove dikarenakan peristiwa yang disebabkan oleh alam seperti terjadinya gelombang besar yang menyebabkan erosi dan abrasi pada hutan mangrove [4]. Kerusakan hutan mangrove yang disebabkan oleh aktifitas manusia seperti adanya penyalahgunaan sumberdaya adalam wilayah pantai yang tidak dijaga kelestariannya, penebangan hutan yang berlebihan, tambak, pemukiman penduduk, industry dan pertambangan [5].
Berdasarkan analisis data citra pada stasiun I, II, dan III menunjukkan kecendrungan penurunan jumlah luasan vegetasi mangrove. Diperkirakan penurunan tersebut terjadi karna adanya pengurangan lahan tumbuh mangrove, pemukiman, perindustrian, pemamfaatan hutan yang berlebihan dan pembuangan bahan pencemar ke lautan.

Menurut [6] penurunan luasan mangrove juga dapat disebabkan oleh dinamika pasang surut perairan pada saat perekaman data citra satelit. Perekaman data citra pada saat pasang akan menyebabkan wilayah daratan yang tergenang oleh perairan akan lebih banyak dibandingkan perekaman data citra pada saat surut

\section{Analisis Kerapatan Mengggunakan NDVI (Normalized Different Vegetation Index)}

Normalized Different Vegetation Index (NDVI) merupakan kombinasi antara teknik penisbahan dengan teknik pengurangan citra. Transformasi NDVI ini merupakan salah satu produk standar NOAA (National Oceanic and Atmospheric Administration), satelit cuaca yang berorbit polar namun memberi perhatian khusus pada fenomena global vegetasi.

Hasil transformasi NDVI diklasifisikan berdasarkan nilai NDVI dengan kategori sangat jarang, jarang, sedang, rapat, dan sangat rapat. Hasil 
Klasifikasi berdasarkan nilai NDVI pada Gambar 18, 19, dan 20.

Tabel 3. Klasifikasi NDVI

\begin{tabular}{ccc}
$\begin{array}{c}\text { Nomor } \\
\text { Band }\end{array}$ & Kriteria & NDVI \\
& $0,1-0,2$ & Sangat Jarang \\
\cline { 2 - 3 } Band & $0,2-0,3$ & Jarang \\
\cline { 2 - 3 } 564 & $0,3-0,5$ & Sedang \\
\cline { 2 - 3 } & $0,5-0,6$ & Rapat \\
\cline { 2 - 3 } & $0,6-0,8$ & Sangat Rapat \\
\hline
\end{tabular}

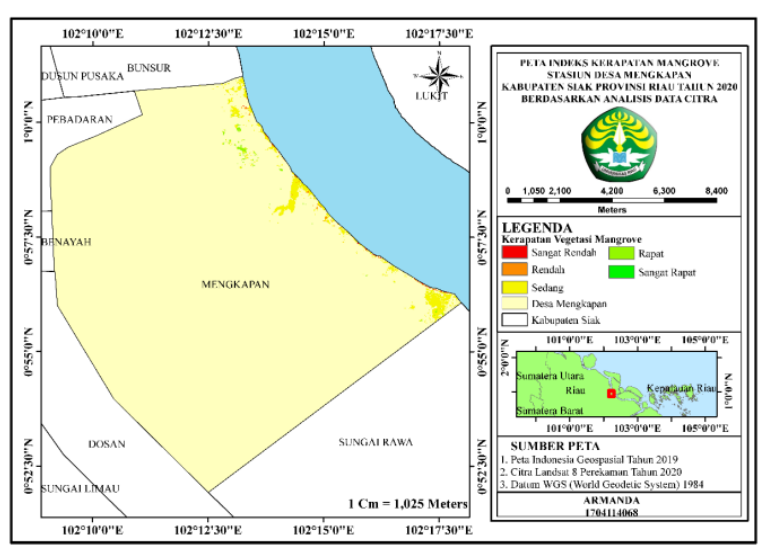

Gambar 18. NDVI Stasiun I (Desa Mengkapan) Tahun 2020
Hasil klasifikasi berdasarkan nilai NDVI vegetasi mangrove di Kecamatan Sungai Apit menunjukkan perbedaan persentase kerapatan dan tutupan berdasarkan kategori sangat jarang dengan nilai $0,1-0,2$, kategori jarang dengan nilai $0,2-0,3$, kategori sedang dengan nilai $0,3-$ 0,5 , kategori rapat dengan nilai $0,5-0,6$ dan kategori sangat rapat $0,6-0,8$. Nilai NDVI di Kecamatan Sungai Apit adalah sedang dengan nilai $0,3-0,5$, kategori rapat dengan nilai $0,5-0,6$ dan kategori sangat rapat $0,6-$ 0,8 .

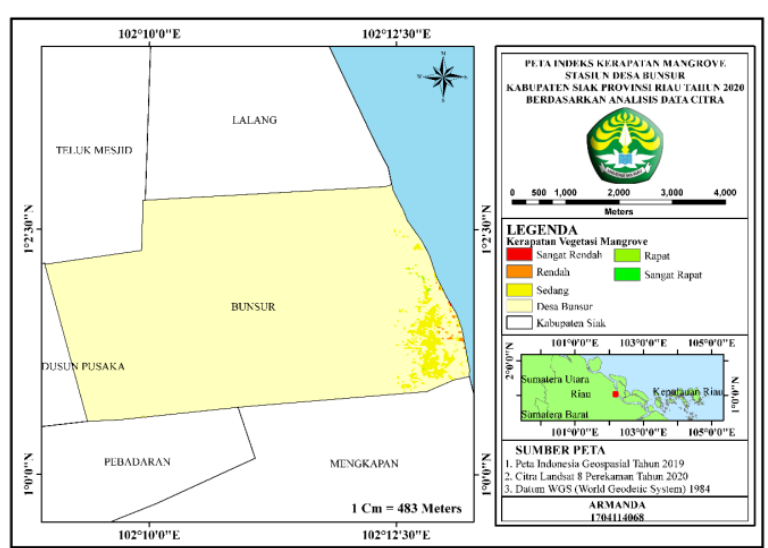

Gambar 19. NDVI Stasiun II (Desa Bunsur) Tahun 2020

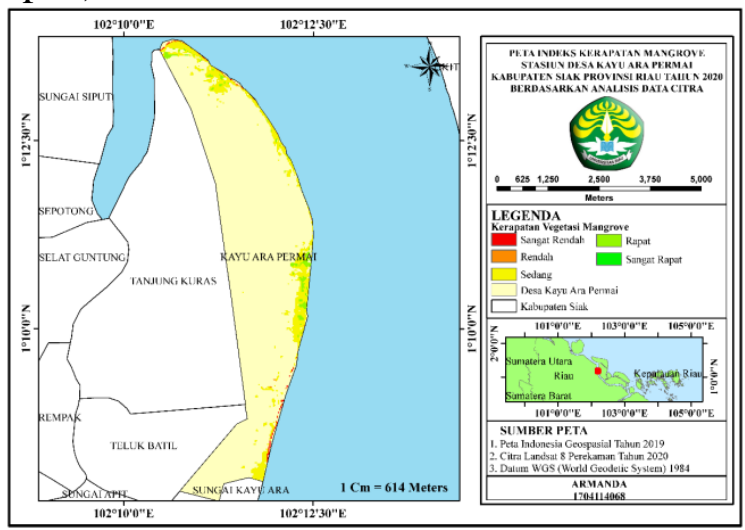

Gambar 20. NDVI Satsiun III (Desa Kayu Ara Permai) Tahun 2020

\section{KESIMPULAN DAN SARAN}

\section{Kesimpulan}

Hutan mangrove dengan luas tertinggi yaitu pada tahun 2000 dengan luas vegetasi mangrove mencapai 7990,59 ha dan terjadi penurunan dengan angka terendah pada tahun 2015 dengan luasan vegetasi sebesar 486,43 ha dan pada tahun
2020 luas vegetasi mangrove sebesar 497,51 ha. Secara keseluruhan sebannyak $79 \%$ luasan hutan mangrove telah rusak atau beralih fungsi dalam jangka waktu 20 tahun. Nilai NDVI di Kecamatan Sungai Apit adalah sedang dengan nilai 0,3-0,5, kategori rapat dengan nilai $0,5-0,6$ dan kategori sangat rapat $0,6-0,8$. 


\section{DAFTAR PUSTAKA}

1. Bengen, D.G. (2001). Pedoman Teknis Pengenalan dan Pengelolaan Ekosistem Mangrove, Pusat Kajian Sumberdaya Pesisir dan Lautan. Institut Pertanian Bogor. Bogor

2. Rusdianti, K. (2012). Konservasi Lahan Mangrove serta Upaya Penduduk Lokal dalam Merehabilitasi Ekosistem Mangrove. Jurnal Sosiologi Pedesaan, 6(1):1-17

3. Prahasta, E. (2005). Sistim Informasi Geografis (Konsep-Konsep Dasar Perspektif Geodesi dan Geokimia). Bandung: CV. Informatika.

4. Fadlan, M. (2011). Struktur Komunitas Mangrove di Desa Dompas Kecamatan Bukut Batu Kabupaten Bengkalis Provinsi Kepulauan Riau.Universitas Riau. Pekanbaru.

5. Peraturan Mentri Kehutanan Republik Indonesi Tahun Nomor: P.12/Menhut-12/2012 Tentang Tata Cara Penyusunan Rencana Teknik Rehabilitasi Hutan dan Lahan Daerah Aliran Sungai.

6. Iqbal,M. (2011). Deteksi Perubahan Luas Penurupan dan Kelebatan Mengrove di Kabupaten Belitung Timur dengan Menggunakan Citra Satelit Landsat. Bogor.(ID): Institut Pertanian Bogor 